\title{
Complaint Monitoring System Using Android in Iraq
}

\author{
Raghad Baker Sadiq Majeed \\ College of Businesses Informatics \\ University of Information Technology \& Communications \\ bakiermajid@yahoo.com
}

\author{
Recived : $18 \backslash 12 \backslash 2017$ \\ Revised : 28\12\2017 \\ Accepted : $8 \backslash 1 \backslash 2018$
}

Available online : $\quad 20 / 2 / 2018$

DOI: $10.29304 / j q c m .2018 .10 .2 .368$

\begin{abstract}
Despite the widespread use of smartphones in Iraq and the possession of a vast number of people, the Iraqi environment is still lacking efficient applications that provide a real collaboration between the citizens and government through advanced diverse services. These applications will increase the transparency through monitoring the performance of the government institutions by citizens. Moreover, citizens can enforce the government employees to finish their works efficiently on time. Mayoralty of Baghdad is one of these institutions that contains many municipalities which are responsible for maintaining and running the city. Complaint Monitoring System (M-complaint) is created to help citizens to submit their complaints with photos of problem's locations and track their locations using Global Positioning System (GPS) accurately. Citizens can track their complaints and reply the amount of satisfaction to the solutions which provided by municipalities. In addition, daily, the system will automatically filter the unsolved claims within seven days and submit a notification to the higher authority to find the suitable solutions. The aim of creating this application is to simplify the process of registering a complaint to the municipal and monitor the status of it (solved/not solved) in a quicker and cheaper way. Also, it measures the amount of citizens 'satisfaction depending on the provided solutions. If the problem were not be resolved within seven days, the system would automatically send a notification to the higher authority to follow up neglected complaints and take necessary actions. This system supports transparency and integrity and enables both citizens and officials to follow up on the performance of their employees. It considers as a part of Mobile government (M-government).
\end{abstract}

\section{Keywords:}

Firebase clouding messages (FSM), Smartphones, M-complaint, GPS, Android, JSON, Mgovernment and neglected complaints. 


\section{Introduction}

The citizen has two ways to register a complaint, the first one by calling the municipality many times which usually ends with going to the municipality to report the problem which wastes time and energy because of the paper works. The second one online, either by reporting a complaint on the official website or Facebook [4] or using mobile application that downloaded from Google Play [3]. Although these two ways are considering cheaper, they do not contain accurate information about complaints and also do not monitor the status of claims effectively. Mobiles and wireless technologies enable their users to make information and government services accessible at anytime and anywhere. Mgovernment provides better public services by increasing the interaction between the government and citizens to address their needs and solve their problems through these devices and their technologies like camera, GPS and location services [6]. The main benefits of M-government are increasing transparency, decreasing corruption and reducing the complexity. It makes the information accessible for everybody in an appropriate way that leads to enhancing citizens' freedom [6]. Mayoralty of Baghdad has currently 18 municipalities. Each one has an office which is responsible for solving problems of a particular ward. There are a lot of researchers that have been given rise to a claim including $\mathrm{m}$-services for the use of municipality services [3] to keep citizens' satisfaction.

\section{Related work}

- The official application of Mayoralty of Baghdad.

This existing application can be downloaded from Google Play. The system will register a complaint by uploading or choosing a photo from gallery and write some information about complaints by a citizen. The reply will be written by an employee. Although this application has provided a way for direct communication between the government and citizens, it is considered inefficient because the requested information about complaint and complainant is insufficient. And also, neither authorities and nor employees are able to notify the complaints directly in their work area. Besides, failure to take action in the case of neglected complaints, leading to the weak of using the application and preferring citizens to complain in traditional ways.

- Tejaswita B., Madhuri B. \& Sucheta M.: Mobile Application for Grievance Registration.

The system was designed to lodge and monitor complaints by citizens, employees and an admin. The citizen could upload a photo on application through his/her android phone with a comment after registering to the application and then $\log$ in. A notification or message from an admin would be sent once a complaint was solved. Although the system could increase the efficiency, transparency and know the progress of each municipality through statistics, the system will be dealt with neglected complaints by sending them to the higher authority by an admin (not automatically). 
- Mareeswari V. \& Gopalakrishnan V.: Complaint go: an online complaint registration system using web services and android.

The system contained two interfaces: mobile application and web portal to report complaints by citizens to Higher Government bodies directly. The location could be shared easily using Google map. The system allowed to attach any multimedia content such as an audio or video file. After lodging, a PIN coder would be generated for each complaint. It would be used with FSM to announce the Android users about the status of the complaint whether was solved or still remaining in the pending state. The system did not deal with neglected complaints.

- Radhakrishnan D., Gandhewar N., Narnaware R., Pagade P., Tiwari A.\& Vijaywargi P. : Smart Complaint Management System.

In this system, citizens reported complaints by tracking the specific locations using GPS and uploading pictures of them. Also, employees can use it to manage the complaints to track the status of the complaint easily. The system would keep on remaindering the employee about the pending complaint or unsolved problems. So, a problem would not be solved until the employee decides to solve it. In another word, any complaint could be neglected.
- Bomble T., Raut R., Kanekar R. \& AhmadHusen Sh.: Android Based Complaint Management System for Municipal Corporation.

The system was designed to register problems of citizens in particular areas by attaching photos and GPS track. The system used an alarm that would buzz when any complaint was not processed after a period time to notify that the complaint was being lodged for a long time and no processing was taken. Also, it was generated an e-mail when a complaint was registered, any complaint had not been followed up after a period time or sending a complaint to a department. There was no processing if the alarm had been buzzed and ignored.

\section{Purpose of the system}

This paper investigates an android application of mobile helping citizens to submit, monitor and track complaints easily from smart mobiles and get their problems solved without any efforts. The first objective of this application is providing facilities to the citizens when reporting their problems and making employees in municipality follow up to solve them from their mobiles. The second objective is reducing the corruption either by making the managers monitor the performance of their employees through the citizens' satisfaction or submitting a notification to the higher authority to find the suitable solutions if a complaint is not resolving within the stipulated time. This system is an attempt to bring transparency into the operation of Government Corporations. 


\section{Proposed system}

This system is a complaint launching and tracking system. The implementation of the system is shown in figure 1 .

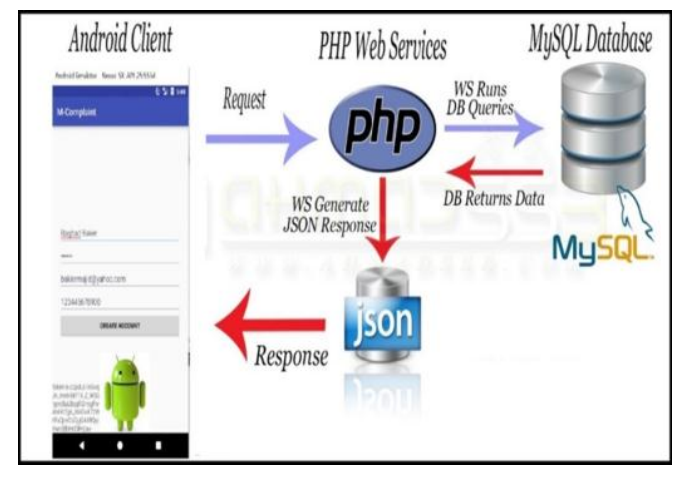

Figure 1. The architecture of the system

A. Client-side: in client side, there are three types of users, complainants, employees who are responsible for solving the complainants' problems in each municipality and the higher authority who will be sent the neglected complaints that were not being solved within seven days. All of them need to download and install the application to use it with Android Mobile phone. First, the user needs to fill up the information (username, password, phone number, and e-mail) correctly to be registered. After submission the information, a unique number, named the registration ID, will be generated and saved in the database which will be used to send notifications through FSM. If the user registered correctly, they can log in as shown in figure 2 , then the main page will appear.
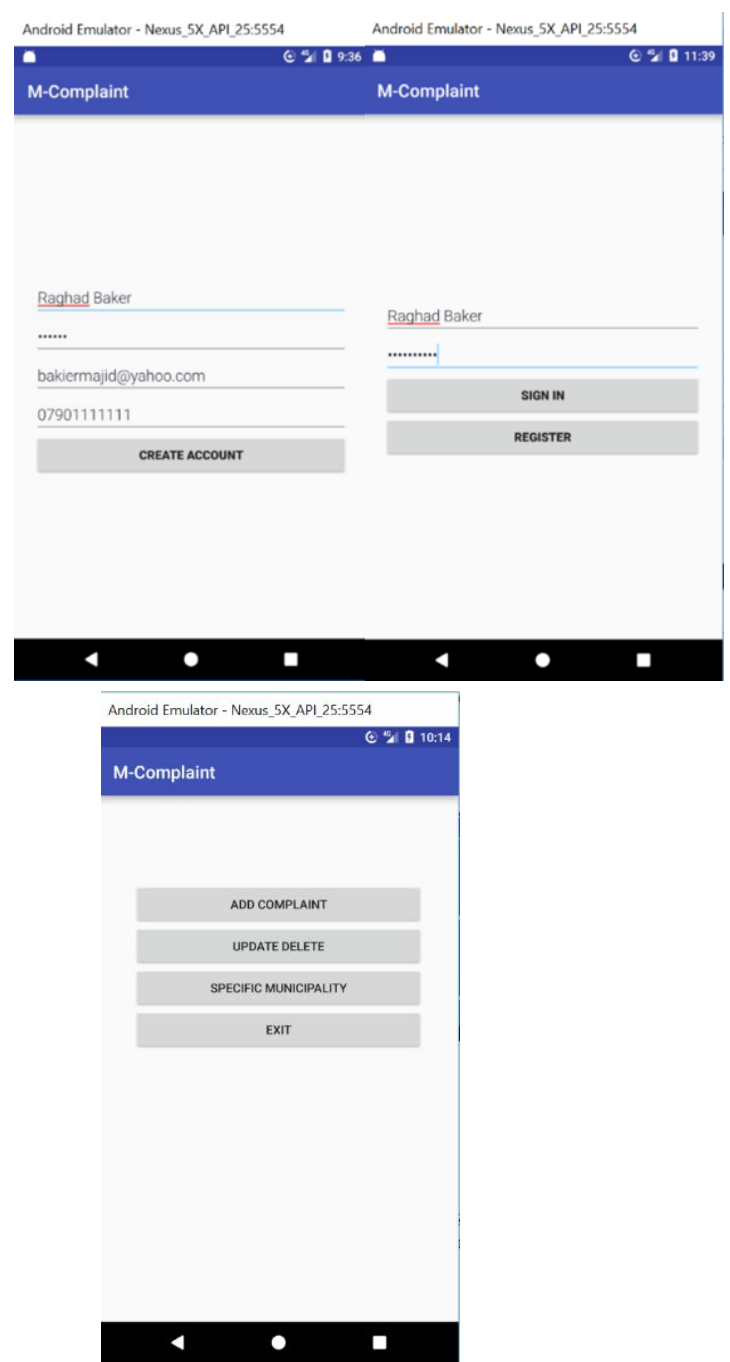

Figure 2. Login, registration and main page

A complainant can report a new complaint, check or update all the complaints that were previously listed by him/her if any of them has been updated. A complainant can fill fields fast and easily (most of the fields can be filled up by picking up the options) to reduce efforts. Besides, the address can be filled by written or using GPS and a photo of the specific area can either take it by camera or upload from the gallery as shown in figure 3 . 


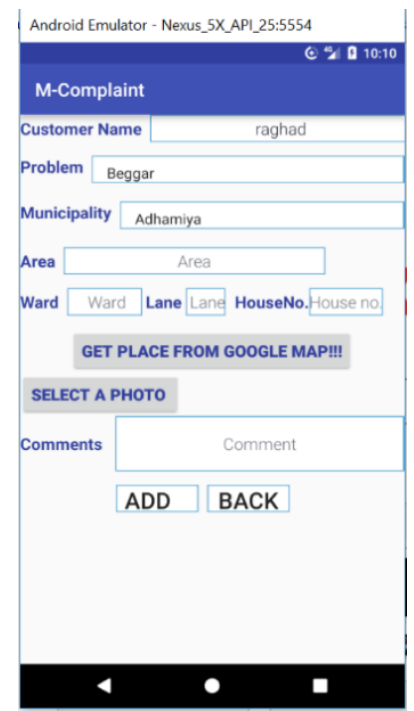

\section{Figure 3. New complaint}

Also, complainants can rate the solutions and this is a way to monitor the performance of each municipal by managers. In addition, this application uses push notifications by FCM for each modification. For example, when the complaint is submitted to the server, a notification will be sent both to the concerned complainant and to the relevant employees who saved in a group in the server to announce that a new complaint has been saved. So, employees in specific municipal can also monitor the problems easily that fall within their responsibility and respond to them. Another way to track the problems by employees is to open the application and select specific municipality, the problems will be appeared relating to their municipality as shown in figure 4 . The third user is the higher authority who will be sent the neglected complaints.
If a complaint were not being solved within seven days, it will be automatically sent a push notification to the higher authority from the server phone to announce that there are neglected complaints.
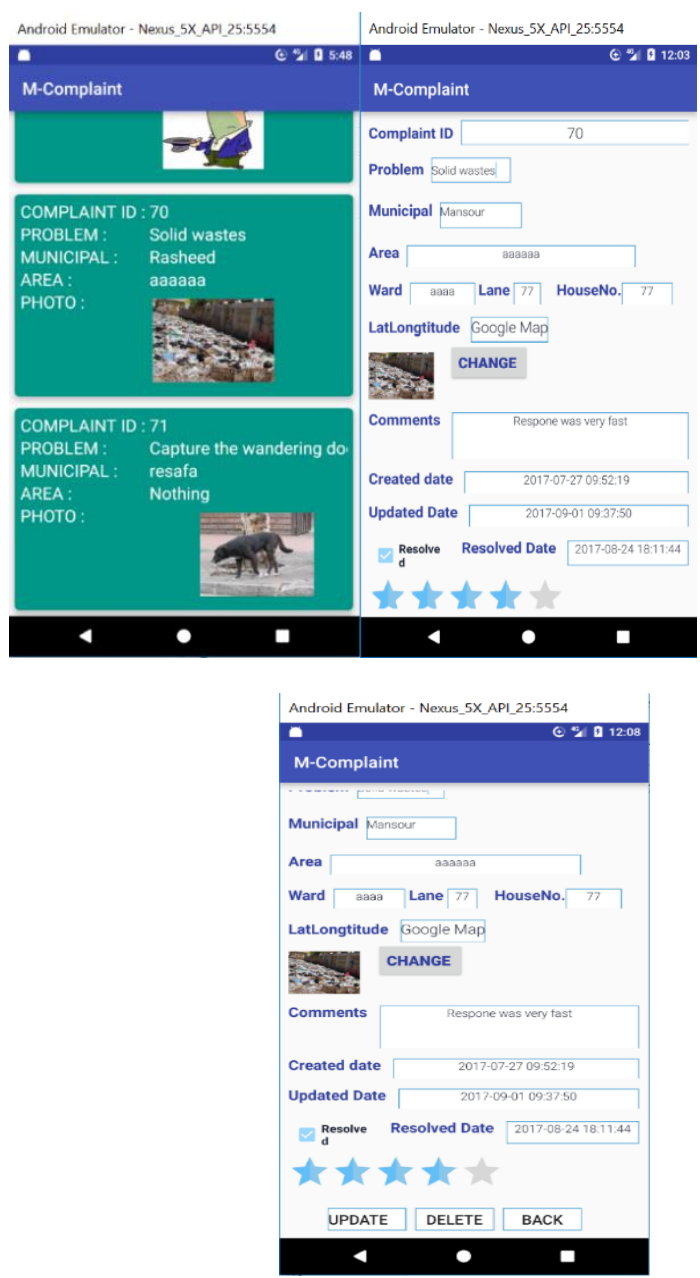

Figure 4. Complaints of specific municipality 
B. Web Server: This part is the engine of the system which is the link between the Android application and the database. XAMPP Server has been used to host PHP project's files that are responsible for data transaction (as a Javascript Object Notation (JSON)) between the database and the application. Also, the system uses to upload and download images from web service which are stored in a specific folder on the server. The system also uses FCM to send notifications, for example, if a new complaint is reported or modified, the system will send one to the concerned complainant by keeping the registration ID of his/her device in the database. To reduce the corruption, two files added to the web server, named cron.bat and cron.php. These two files with tools named Task scheduler (in Windows) are responsible for capturing all complaints that are not solving within the stipulated time (seven days) to put them in a separate table and send a notification to the higher authority about them. This operation will be done at a particular time every day.

C. Database-side: this system uses MySQL as a database to store the data. It contains three tables, Logins table uses to store users' information (as mention above), Complaints table uses to store problems' information and finally Delay table uses to store complaints' information automatically that were not being solved within seven days. A column in Complaints table is used to store the latitude and longitude from GPS. All tables store the time and the date creation and modification automatically. The images will be stored in a specific folder (on the server) and the path of each one will be stored in the table. Figure 5 shows the table of complaints.

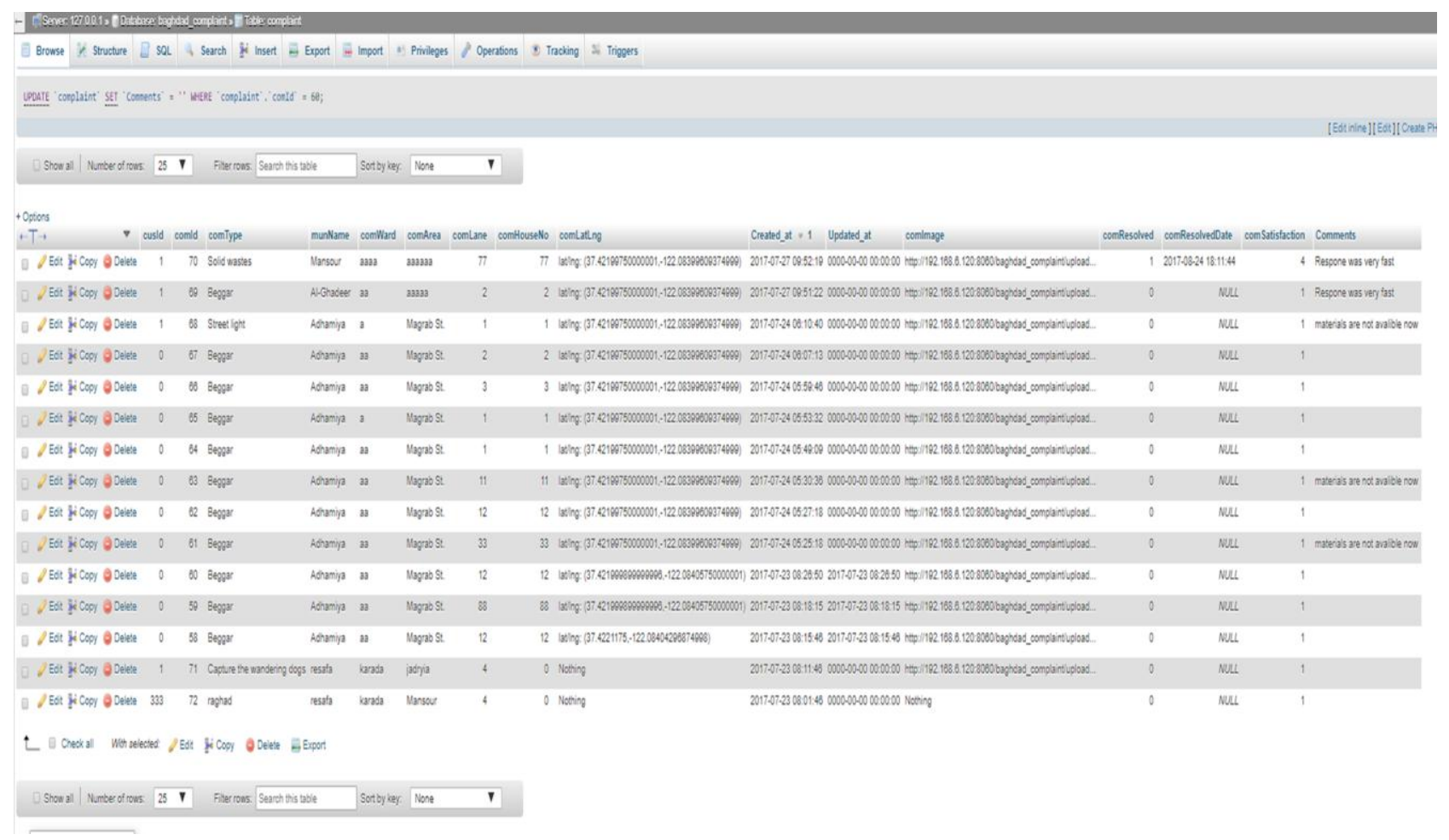

Figure 5. Table of complaints 


\section{Analysis of performance}

Complainants can rate the solutions of the problems to show the amount of their satisfaction with the performance of their municipality. Also, it can use the number of neglected complaints to measure the time of response to solve them. The following chart explains the experiment of using the system for four weeks (from week 2 to week 5). The following chart indicates the amount of performance in municipalities depending on the rating of citizens and the number of neglected complaints. In the first week, the performance was very low, in contrast to the remaining weeks, it showed increasing in citizens satisfaction to the provided services in municipalities and decreasing in the number of unresolved complaints.

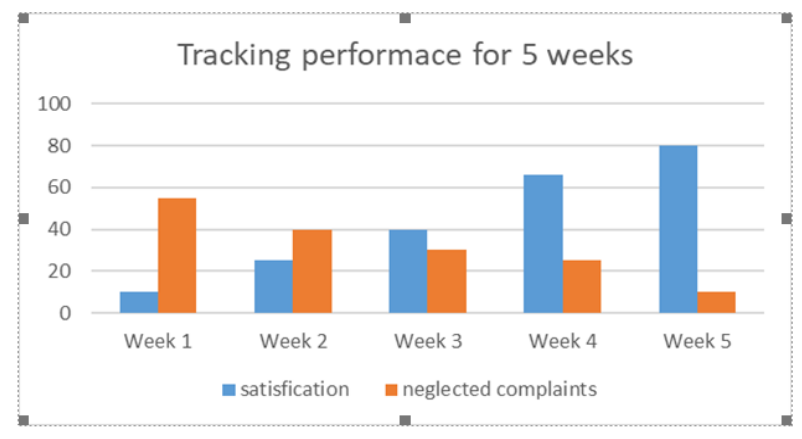

Figure 6. Tracking Performance for 5 weeks

\section{Advantages of system:}

1. Increasing the accuracy and transparency.

2. Reporting complaints anywhere and anytime in a very short period of time and easy.

3. Reducing efforts and time waste.

4. Monitoring the process of complaint would be easy.

5. Cost-free and user friendly.
6. Enforcing the government employees to finish their works efficiently on time.

\section{Conclusions}

In this paper, we have proposed and introduced a system which contains an Android application of mobile for citizens to report complaints by uploading a picture of a suspected place and use GPS to provide the location where the problem has appeared and other required information in a very short period of time. Besides citizens, the system allows employees and authorities to deal with complaints easily and friendly. They can check and update the information, especially the status of the complaints. The system will send a mobile notification to the complainant and the concerned employee after each modification through FSM. Citizens can rate the solutions which introduced by the municipality. The system makes the managers keep an eye on the quality of work of the municipality's employees and decrease the corruption by sending neglected complaints to the higher authority without efforts and time waste. Furthermore, it enforces the employees to finish their work on time which leads to increase the accuracy and transparency according to the results that have mentioned before. This system is considering as part of M-government which increases the communication between the government in a specific field and the people by using mobile. In the future, the system can be developed to dealing with fake complaints. It can develop a mobile application for IOS phones. Also, it can relate to Big Data to provide more facilities. 


\section{References}

1. Tejaswita B., Madhuri B. \& Sucheta M. (2017). Mobile Application for Grievance Registration, Imperial Journal of Interdisciplinary Research (IJIR). Retrieved September 19, 2017 from http://ijcset.net/docs/Volumes/volume 7issue4/ijcset2017070403.pdf

2. Mareeswari V. \& Gopalakrishnan V. (2017). Complaint go: an online complaint registration system using web services and android, IOP Conference Series: Materials Science and Engineering. Retrieved September 10, 2017 from http://iopscience.iop.org/article/10.108 8/1757-899X/263/4/042073/pdf

3. Mayoralty of Baghdad (2016). Retrieved August 28, 2017 from https://www.amanatbaghdad.gov.iq/ 4. Mayoralty of Baghdad (2016). Retrieved August 26, 2017 from https://www.facebook.com/\%D8\%B4 \%D8\%A4\%D9\%88\%D9\% 86\%D8\%A7\%D9\%84\%D9\%85\%D9\%8 8\%D8\%A7\%D8\%B7\%D9\%86\%D9 \%8A\%D9\%86-\%D9\% 81\%D9\%8A\%D8\%A7\%D9\%85\%D8\%A7\%D9\% 86\%D8\%A9$\% \mathrm{D} 8 \% \mathrm{~A} 8 \% \mathrm{D} 8 \% \mathrm{BA} \% \mathrm{D} 8 \% \mathrm{AF} \% \mathrm{D} 8$ \%A7\%D8\%AF-379378492099863/
5. Radhakrishnan D., Gandhewar N., Narnaware R., Pagade P., Tiwari A.\& Vijaywargi P. (2016). Smart Complaint Management System, International Journal of Trend in Research and Development (IJTRD). Retrieved August 30, 2017 from https://www.ijtrd.com/papers/IJTRD5397.p $\underline{\mathrm{df}}$

6. Sapkale S. C. \& Kulkarni-Bhende R. (2015). Mobile Enabled Governance for Local Governments in India, Indian Journal of Computer Science and Engineering (IJCSE). Retrieved Septemeber 1, 2017 from http://www.ijcse.com/docs/INDJCSE1506-03-068.pdf

7. Bomble T., Raut R., Kanekar R. \& AhmadHusen Sh. (2015). Android Based Complaint

Management System for Municipal Corporation, Journal of Technology Engineering Research and Applications. Retrieved September 1, 2017 from http://www.ijera.com/papers/Vol5_issue4/ Part\%20-\%203/J504036466.pdf

8. Fernandes M., Britto M. \& Francis F. (2015). Android Based Complaint Management System: People's Corner, International Journal of Innovative Research in Computer and Communication Engineering. Retrieved September 3, 2017 from

https://www.ijircce.com/upload/2015/april/ 55_12_Android.pdf 


\section{نظام مراقبة الشكاوى باستخدام الاندرويد في العراق}

\section{رغد باقر صنادق مجيد \\ كلية معلوماتية الاعمال / جامعة تكنولوجيا المعلومات والاتصالات \\ bakiermajid@yahoo.com}

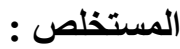

على الرغم من الاستخدام الواسع للهواتف الذكية في العراق وحيازته من قبل عدد كبير من الناس، إلا أن البيئة العراقية لا تزال تفتقر إلى التطبيقات الفعالة التي توفر تواصلا حقيقيا بين المواطنين والحكومة لتوفير الخدمات المتنوعة.بالاضافة ان توفر هذه التطبيقات سيؤدي إلى زيادة الثفافية من خلال رصد أداء المؤسسات الحكومية من قبل المواطنين. وعلاوة على ذلك، يمكن للمو اطنين اجبارموظفي الحكومة لإنهاء أعمالهم بكفاءة في الوقت المحدد. بلدية بغداد هي و احدة من هذه المؤسسات التي تضم العديد من البلديات المسؤولة عن المحافظة على المدينة و إدارتها. تم إنشاء نظام مراقبة الثكاوى (M-complaint) لمساعدة المواطنين على تقديم شكاو اهم مدعومة بالصور من مو اقع المشكلة وتتبع مو اقعه باستخدام نظام تحديد المواقع العالمي (GPS) بدقة. يمكن للمو اطنين تتبع شكاو اهم و بيان مدى الرضا عن الحلول التي تقدمها البلديات. وبالإضافة إلى ذللك، يوميا، سيقوم النظام تلقائيا بتصفية الشكوى التي لم تحل في غضون سبعة أيام وتقديم إخطار إلى السلطة العليا لإيجاد الحلول المناسبة. ان الهدف من إنشاء هذا التطبيق هو لتبسيط عملية تسجيل شكوى إلى البلدية ورصد حالتها ( تم حلها / لم تحل) بطريقة أسرع وأرخص. كما أنه يقيس مقدار رضا المواطنين على الخدمات اعتمادا على الحلول المقدمة. هذا النظام يدعم الشفافية والنزاهة ويتيح للمو اطنين و المسؤولين متابعة أداء موظفيهم. وهي تعتبر جزءا من الحكومة المتنقلة (M-government).

كلمات مفتاحية: Firebase clouding messages (FSM) ( M-government ، JSON الاندرويد، (GPS) 